\title{
解
}

\section{自動車における制振と 防音の予測技術}

Presiction of Vibration Damping and Sound-proof Properties for Automotive Structures

\section{執筆者プロフィール}

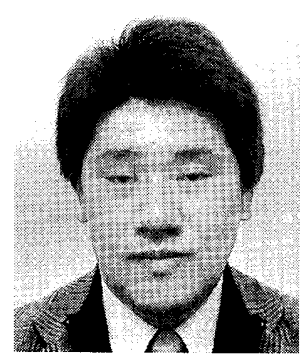

○1986 年名古屋大学工学部卒業. 同年, 富士重 工業（株）に勤務. 2000 年群馬大機械システ 厶工学科に奉職. 工学博士

○研究・専門テーマは，自動車等構造の制振防 音, 動特性数值解析, カオス

○正員, 群馬大学准教授 大学院工学研究科機 械システム工学専攻

(厂376-8515 群馬県桐生市天神町 1-5-1

E-mail : yamagme4@me.gunma-u.ac.jp)

山口 誉夫

Takao YAMAGUCHI

\section{1.」はじめに}

自動車の車体には粘弾性体である制振材が積層して利用 されている。 また，本室内やエンジンルーム内には多孔質 材が吸音あるいは遮音のために配置されている。これらの 材料の減衰効果を考慮した有限要素法により自動車の制 振，防音特性を解析した例を紹介寸る。このような材料が 混在する系の減衰特性や応答の高速計算法についても言及 する。

\section{2. 自動車の制振防音構造}

自動車での車内音の代表的な例としてロードノイズがあ る。これは路面の微少な凹凸を起振源とする振動が, 夕イ ヤ 車体の骨格部材などの伝達系を伝搬し，車室を構成するパ ネルで車室内へ放射される音である，運転中に加速してい ない時にバックグランドで”ゴー”あるいは”ザー”と聞 こえる音として体感できる。この車内音を低隇するため起 振源, 伝達系, 放射系, 受音部にわたり多くの対策が施さ
れる．放射系である車体パネルは受音部（乗員の耳）に対 して音波が通過する最終表面となり，多くの起振源，音源 の影響が集約された部分となるので手厚い制振防音対策が なされる。

図 1 に車体パネルの積層制振防音構造を示す(1)、鋼製の 車体パネルではビードや曲面によってパネル剈性が高めら れる，その上に制振材（粘弾性材）を積層し減衰を付加し 振動低減を図っている。ただし，制振材による減衰はパ六 ルの剛性の影響をうける(一般には剛性を高めると減衰が 減ってしまう.）のでパネル形状と減衰効果の最適化が必 要となる ${ }^{(1)(12)}$ ，その上に瀻維材あるいは樹脂発泡材から なる吸音層（多孔質材），さらにその上にカーペットなど の内装が積層される構成となっている，遮音シート（粘弾 性材）を多孔質材と内装の間に挿入する場合がある。この 組み合わせによりパネルからの振動が車室に音として放射 されるのを遮断している，柔らかい吸音層（多孔質材）を

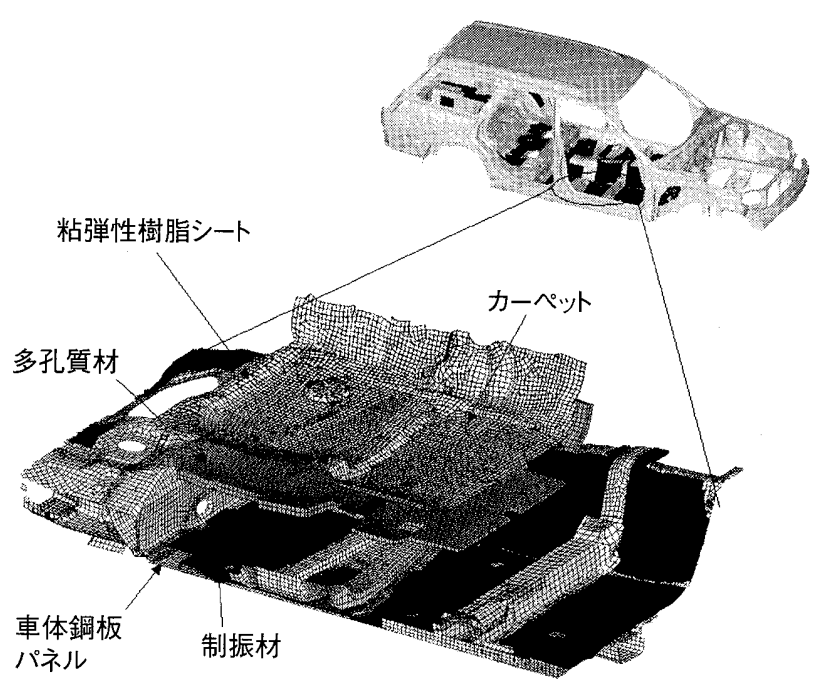

図 1 車体の制振防音構造の計算モデル(1) 
パネルと遮音シート（粘弾性材）とで挟むことにより, 起 振源, 音源から伝搬したパネルの振動が車室側のカーペッ トや遮音シート（粘弾性材）に伝達する効率を減らす効果 を利用している(二重壁による遮音)，ただし，二重壁遮 音構造では鋼製パネルと遮音シート（粘弾性材）とが質量 になり，吸音層（多孔質材）がばねとなる共振があらわれ， その周波数帯では, 放射音が増幅してしまう。

現実の自動車部品の中での二重壁遮音構造には，それ以 外の性能劣化要因がある。二重壁構造のどこかの層が欠落 する部分が存在すると音響的な孔となり，遮音効果は損な われる。これは，冷暖房関連の部品や操作部品などのレイ アウトによってできてしまう，

車室内に入ってきた音が反射し干渉し共鳴となり, 音圧 のピークとなる.ルーフトリム，カーペットやシートなど で吸音することが行われる。

以上のように車体の制振防音構造には複雑な要因が関わ りあっており, ち密な最適設計が要求される. また, 前述 したとおり, 制振防音構造は弾性体, 粘弾性体, 多孔質体, 気体が複合した構造になっており，CAE 適用にはそれら の連成解析が必要となる。

\section{3. 解析手法}

ロードノイズは，ほぼ車体全体（車体骨格, 車体パネル， サスペンション, タイヤ, 内装, ほか）の振動特性が影響 する。また, 他の性能要件 (衝突, 強度, 空力, プレス成 形性, 軽量, 操縱安定性, 部品取り付け, ほか) とトレー ドオフの関係になることが多い.したがって，CAEによ る設計は, 他の性能要件のための CAE ともコンカレント に実施される必要がある。また，多種多様な要求性能があ るために，車体は，いったん，図面ができてしまうと，大 きな設計変更が困難となる，よって，試作車を作成する前 にCAEによって, 問題点が提起され，対策の検討がなされ， その後に試作車が製作されることになる。試作車は多額の コストと長期製作期間がかかるので, CAE は性能設計に よる性能向上, 軽量化, コスト削減という効果のみならず, 開発の効率化によるコスト削減の効果が大きい

さて，CAEにより制振防音設計を実施する上で，問題 となるのは減衰の計算手法である，特にロードノイズを対 象とした場合，車体の詳細な結合，形状が振動特性に影響 するために，計算モデルも詳細な形状を再現したものが必 要となり, その結果, 計算モデルは大規模自由度になる. 著者が知る例では，固体音成分が主要となる周波数領域 $(30 \mathrm{~Hz} \sim 500 \mathrm{~Hz})$ をカバーするためには図 1 のような 200 万自由度程度の有限要素モデルが解析に必要となる ${ }^{(11)}$. 先述のと抢り車体パネル周辺の防音構造は固体（弾性材， 粘弾性材) と多孔質材と気体（空気）とが混合して形成さ れている(1).したがって，任意の形状が扱え，制振防音構 造の減衰を含む大規模問題に対応可能な振動解析法が計算
手法として選択される。

建築構造の制振防音設計には，主に拡散振動あるいは拡 散音場を仮定した幾何音響のアプローチが古くから研究さ れており，確立されてきている，自動車においても高周波 数音については, 拡散場を前提としたSEA 法などが用い られてきている(2) (4). しかし, 自動車の車体パネルの振 動場や車室内音場は，問題となる波長に比べ小さく拡散場 とはみなせない場合も多い，この場合には，数値計算法と して, 定在波を含んだ振動音響連成問題を，制振防音材の 減衰を考慮し解析する手法が必要である。

著者らは固体と多孔質材と空気とが混在する場の振動音 響連成問題の減衰特性を数值解析する手法を提案してい る(5)(6). 以下に，その手法の概要を説明する.

多孔質材については，内部の空気に関する音場を有限要 素で離散化し用いる，そのために微小振幅の条件のもとで 周期的に加振される非粘性圧縮性完全流体の運動方程式 と，圧縮性を考慮した圧力と体積ひずみの関係式を用いる。 通常の音響解析では，これらの式から粒子変位を消去して 圧力を未知数とする運動方程式を導くことが多い．ここで は両式から圧力を消去して粒子変位を未知数に残す，この 方法のメリットは, 固体と音場で未知数を共通のパラメー 夕である変位でそろえられることである。これより固体要 素と音響要素の重ねあわせを簡単化できる.固体と多孔質 材と空気が混在する制振防音問題には有利な計算法とな る。

つぎに要素内の粒子変位と節点の粒子変位との関係を内 挿関数で近似する.非回転条件を考慮して, 運動エネル ギー,ひずみエネルギー, 外力による仕事を求め, 最小原 理を用いると線形の圧縮性完全流体の要素の運動方程式を 得る。多孔質材の内部の音場を表すモデルの1つに, 密度 と音速あるいは体積弾性率を複素数とするモデルが提案さ れて扔り，有効性が検証されている(7)、気体の要素方程式 で, 密度と体積弾性率を複素数とすることで, 多孔質材の 要素方程式を求めることができる，このモデルは主に繊維 材について用いられる。多孔質材を形成する骨格を伝わる 弾性波の影響を無視し, 多孔質材内部空気の運動が支配的 と仮定するものである，骨格の材質が，充分に柔軟で，減 衰が大きい多孔質材については，モデルの有効性が実証さ れている(5)(6)(1). 自動車用の防音材には，この条件にあて はまる材料も用いられる、いっぽう，多孔質材を形成する 骨格が硬い場合は，内部空気を伝搬する波動に比へ，骨格 材を伝搬する弾性波の影響が大きくなり，本モデルは不適 となる，その場合はBiot モデルなどが必要となる ${ }^{\left({ }^{(8)(9)} .\right.}$

いっぽう,弾性体は通常の線形有限要素でモデル化する. 粘弾性体の要素方程式は弾性体の要素方程式中のヤング率 を複素数とすることで得られる，対象とする場の全要素に ついて要素方程式を，境界条件を考虑して，重㸚わせ全 系の離散化方程式が得られる。

さらに著者らは各要素のモード減衰に対する寄与度も定 

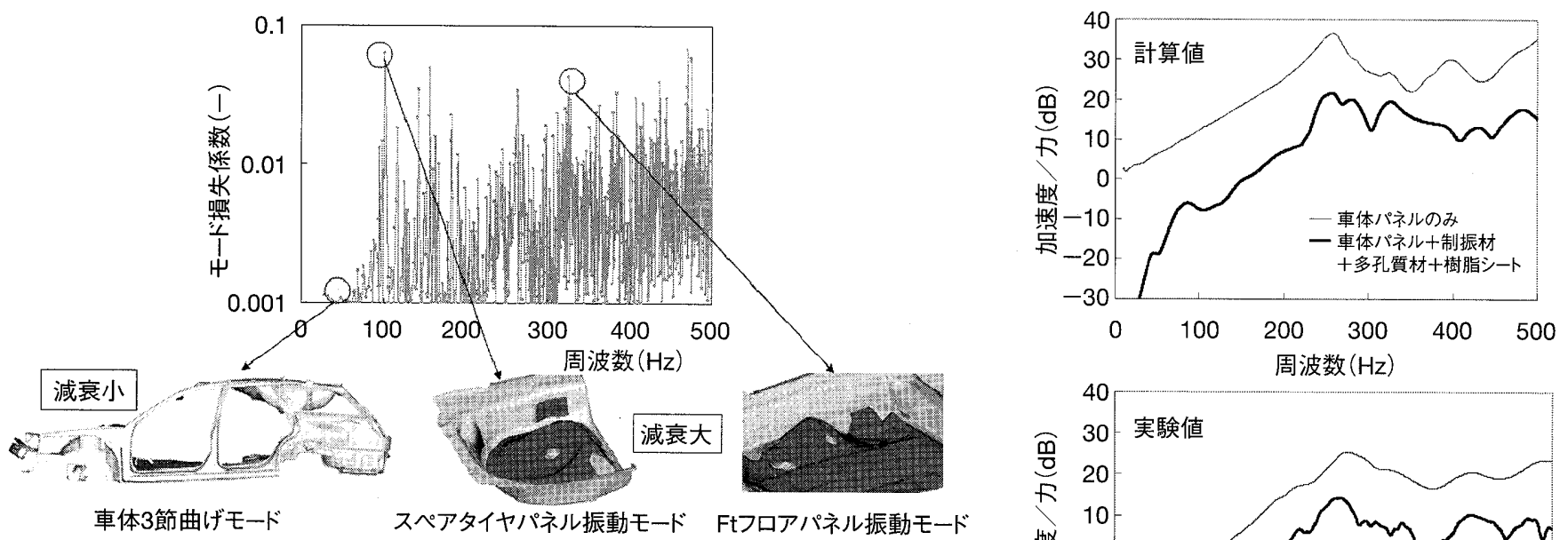

図 2 車体の固有モードと減衰値 ${ }^{(11)}$

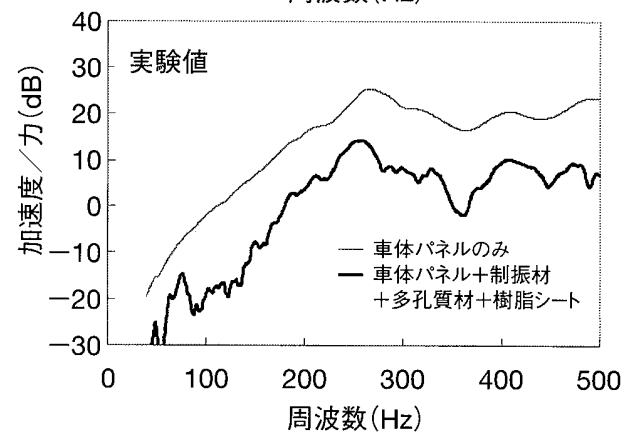

図 3 車体制振防音構造の周波数応答解析例(1)

式化した (5)(6). そのために全系の離散化方程式の複素固有 值問題に対応する式の減衰パラメータに微小量を導入す る. 微小量の 0 次と 1 次のオーダまでをまとめて整理する ことで，モード損失係数の近似式が得られる，近似式より モード損失係数は力一変位間ヒステリシスに関連する材料 減衰とひずみエネルギー分担率との積の全要素にわたる和 および流れ抵抗に関連する材料減衰と運動エネルギー分担 率との積の全要素にわたる和から計算できることにな る。この式は，粘弾性体と弾性体とが混合した構造のモ一 ド減衰を計算する Modal Strain Energy Method ${ }^{(10)}$ を拡張し た手法である。著者らは提案した手法を Modal Strain and Kinetic Energy Method と呼んでいる(5)(6)。近似式中の各工 ネルギーの計算に固有モードが必要であるが，複素固有 モードではなく実固有モードでよい. したがって周波数応 答を実固有值解析で得たモーダルパラメータのみで，きわ めて高速に計算できる，各要素の減衰寄与度もこの近似式 を変形して求められる，減衰寄与度が大きい要素を残し， 小さい要素を除いていくことにより，減衰要素の効率的な 配置が可能となる(11).

\section{1. 車体十制振材十多孔質材十内装の 減衰解析 (11) (1)}

図 1 の解析モデルを用いた。車体＋制振材について図 2 に共振周波数とモード減衰の計算例を示す(11). $500 \mathrm{~Hz}$ 以 下に 1000 個程度の共振が存在する。モードによって減衰 値が異なる，主に骨格および骨格の接合部が変形する振動 モード（骨格モード）ではモード減衰が小さい。これは， 骨格モードでは，ひずみエネルギーが骨格部材とその接合 部に集中し，パネルに積層した制振材に相当する要素のひ
ずみエネルギーが小さく，制振材の効果が得られ難くなる ためである。なお，骨格は主に大きな断面を有する箱型断 面部材で構成されているため曲げ剛性が大きく，仮に骨格 部材に制振材を積層しても，制振材に相当する要素の歪み エネルギーが小さく，制振材の減衰効果は得られ難い。ま たモード減衰が大きいモードは制振材が積層されているパ ネルが面外方向に振動するモード (パネルモード)である。 これは制振材にひずみエネルギーが集中するモードほど モード減衰の值が大きくなるためである。

なお,パネルと骨格が連成する振動モードでは, 骨格モー ドとパネルモードの中間の減衰值が得られる(11)。また, パネルモードにおいても，パネル形状，振動モードによっ て得られる減衰は異なる(12).

図 3 にフロア + 制振材 + 多孔質材 + 内装材の周波数応答 (実験, 計算)の例を示す。実験值と計算值は一致している.

なお，モード減衰に対する制振材各要素の寄与度が求め られ，制振材の配置の検討もできる(11).

起振源，音源側のパネルと車室側にある遮音シート（粘 弾性体) や内装とが硬い部材で連結されると，二重壁によ る遮音効果が劣化する。この時, 柔らかい吸音層（多孔質 材）からではなく硬い部材から振動が伝達してしまうサウ ンドブリッジ効果が起こる，その基礎解析も著者らは行っ ている(6).

\section{5. マフラ+吸音村の減哀解析 (13)}

図 4 の排気系の解析例を紹介する。この場合は，未知数 を粒子変位ではなく音圧として定式化したものを同様な解 析法により用いた(13)，サブマフラにはガラス長繊維の吸 


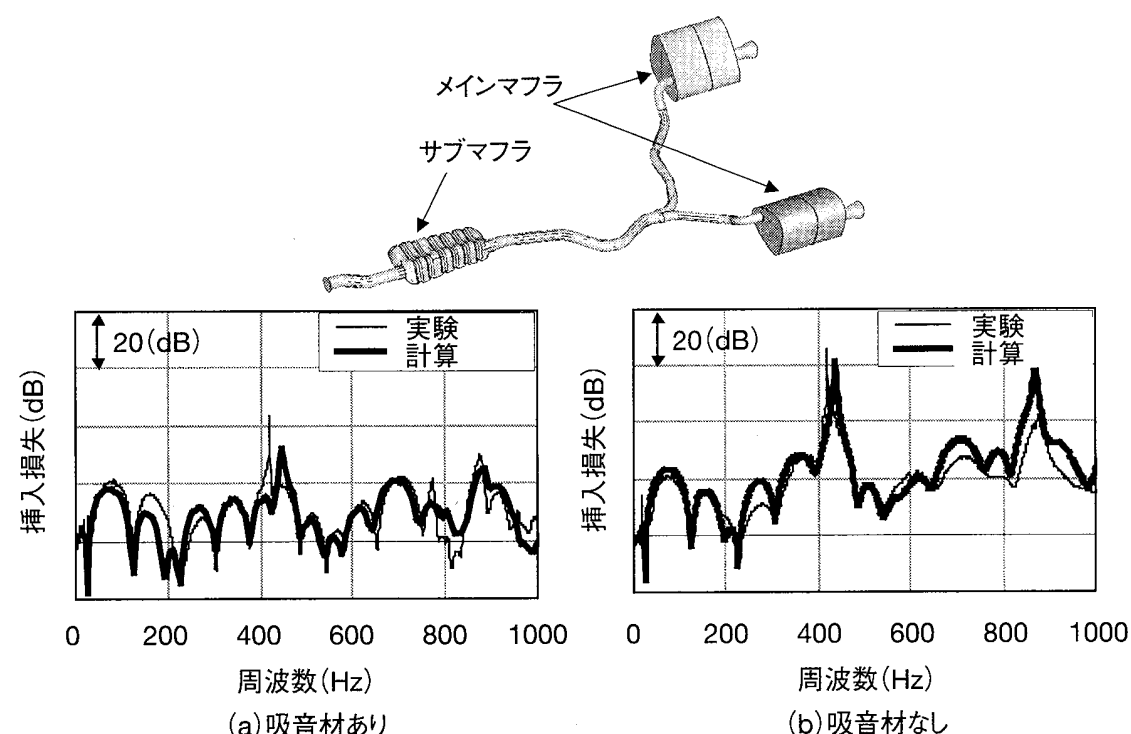

図 4 排気系の消音性能解析例(13)

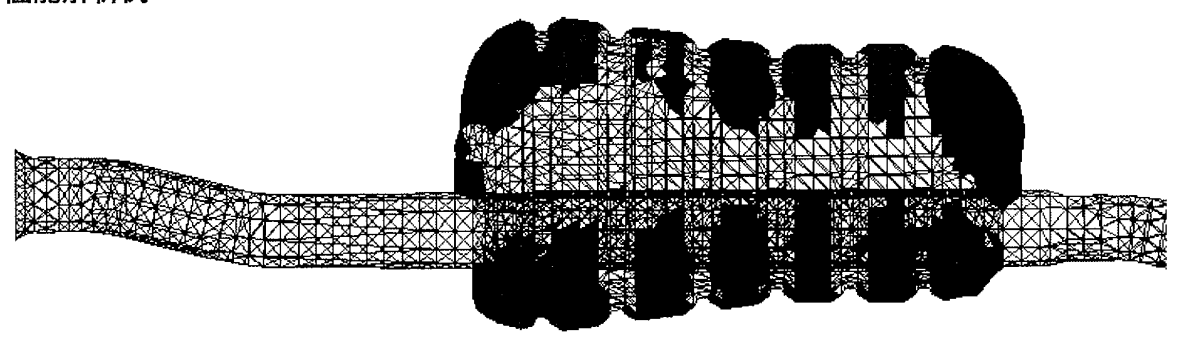

図 5 吸音材の効率的な配置の検討例 ${ }^{(13)}$

音材が充填されている，吸音材がある場合，ない場合につ いて消音性能を実験と解析で求めた。結果を図 4 に示す. サブマフラに吸音材を充てんすることで減音量が増加して おり，それが計算でも再現できている，さらに吸音材の効 率的な配置検討を実施した結果を紹介する。困 5 の黒い要 素は減衰に対する寄与が小さく, 削減対象である。この例 では初期吸音材に対して $26 \%$ の吸音材を削減できた。消 音性能を数值検証した結果, 性能が維持できていた ${ }^{(13)}$.

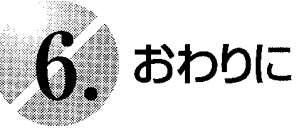

以上, 構造と音場の減衰効果を考慮した有限要素法の解 析法を概説し，それを自動車の制振，防音特性の解析に応 用した例を紹介した。

自動車には, $\mathrm{CO}_{2}$ の排出削減という地球規模の環境に関 わる課題が突きつけられている。 そのために, 内燃機関の 燃焼改善や駆動システムの改良などが検討されている，自 動車の軽量化も燃費向上に関連し, 結果的に $\mathrm{CO}_{2}$ 削減に つながるので, 今後要求がいっそう厳しくなると思われる. したがって軽量化と自動車の静肃性の両立が，ますます困 難となると予想される. 従来, 構造の最適化と減衰のチュー ニングは，別々になされることが多かったと思われる．構 造と減衰の同時最適化が発展し，その解決のための役割の 一端を，将来少しでも担えたら良いと期待している。

（原稿受付 2007 年 1 月 30 日)
文 献

（1）黒沢良夫・山口䇾夫・松村修二，制振材一防音材が積層された 自動車パネルの振動減衰解析, 日本機械学会 Dynamics \& Design Conference 講演論文集, No.05-15 (2005-8).

（2）見坐地一人・山下剛, SEA法による自動車の騒音低減解析技術, 自動車技術，57-7 (2003)，47-52

（3）山崎徹・鎌田実, 統計的エネルギー解析法の自動車振動予測へ の適用に関する基礎的検討，自動車技術会論文集，32-4（2001）, 113-119.

（4）山口久弥，音響材料とその適用技術の動向，自動車技術，57-7 (2003), 88-93.

（5）山口誉夫・黑沢良夫・松村修二, 固体一多孔体一空気からなる 防音構造の減衰特性の FEM 解析, 日本機械学会論文集, 69-677, C (2003)，34-41.

（6）山口誉夫 · 中本英良・黑沢良夫 ·松村修二, 弾性体 - 粘弾性体 多孔体からなる自動車用防音構造のサウンドブリッジの散逸工 ネルギの FEM 解析, 日本機械学会論文集, 71-708, C (2005), 2477-2484.

( 7 ) Utsuno, H., Wu. T. W., Seybert, A. F. and Tanaka, T., Prediction of Sound Fields in Cavities with Sound Absorbing Materials, AIAA Journal, 28-11 (1990), 1870-1875.

( 8 ) Biot, M.A., Theory of Propagation of Elastic Waves in a FluidSaturated Porous Solid, Journal of the Acoustical Society of America, 28-2 (1995), 168-178.

(9) Attala, N., Panneton, R., and Debergue, P., A Mixed PressureDisplacement Formulation for Poroelastic materials, Journal of the Acoustical Society of America, 104-3, (1998), 1444-1452.

(10) Johnson, C. D. and Kienholz, D. A., Finite Element Prediction of Damping in Structures with Constrained Viscoelastic Layers, AIAA Journal, 20-9 (1982) , 1284-1290.

（11）黑沢良夫・山口誉夫・榎本秀喜・松村修二, 制振材が積層され た自動車パネルの振動減衰特性, 日本機械学会論文集, 69-687, C (2003), 2983-2990.

（12）山口誉夫 ·竹前康徳・黒沢良夫・松村修二，制振材を積層した 自動車車体用パネルの減衰特性の有限要素解析, 日本機械学会 論文集，70-699，C (2004)，3062-3069.

（13）榎本秀喜・黒沢良夫・山口誉夫，吸音材を含む自動車用排気系 の消音性能予測, 制振工学研究会 2006 技術交流会資料集 SDT6002, (2006), 5-10. 